\title{
The assessment of subsegmental branches of the pulmonary artery by intravascular ultrasound in patients with mitral stenosis
}

Ocena gałęzi subsegmentalnych tętnicy płucnej za pomocą ultrasonografii wewnątrznaczyniowej u pacjentów ze stenozą mitralną

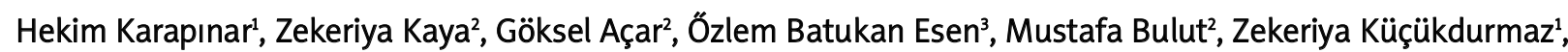 \\ Ibrahim Gül', Mehmet Yazıcıoğlư', Ali Esen², Cevat Kırma \\ 1Department of Cardiology, Cumhuriyet University Faculty of Medicine, Sivas, Turkey \\ 2Department of Cardiology, Kartal Kosuyolu Cardiovascular Research and Training Hospital, Istanbul, Turkey \\ 3Department of Cardiology, Istanbul Memorial Hospital, Istanbul, Turkey
}

Postep Kardiol Inter 2012; 8, 4 (30): 287-292

DOI: 10.5114/pwki.2012.31909

\begin{abstract}
Background: There are limited data that examine the assessment of subsegmental branches of the pulmonary artery by intravascular ultrasound (IVUS).

Aim: To assess the structural characteristics of pulmonary arteries by IVUS in the setting of severe mitral stenosis.

Material and methods: Twenty-one consecutive patients ( 3 men and 18 women; mean age: $38 \pm 11$ years) who were selected for percutaneous mitral balloon valvuloplasty entered the study. Subsegmental branches of the right lower lobe pulmonary artery were imaged by $40 \mathrm{MHz}$ IVUS when the patients underwent right heart catheterization. Minimal lumen diameter (MLD), external elastic membrane diameter (EEMD), lumen area (LA), and area circumscribed by the external elastic membrane (the total vessel area - TVA) were measured. From these measurements, wall area $(W A=T V A-L A)$, intima-media wall thickness [IMT $=(E E M D-M L D) / 2]$, relative wall thickness $(R W T=I M T / E E M D)$, and relative wall area $(R W A=W A / T V A)$ were derived.

Results: We were able to perform the IVUS examination in all patients without complications. Several IVUS anatomic indexes correlated with hemodynamic data. Pulmonary artery IMT, RWT, and RWA correlated significantly with pulmonary artery systolic pressure $(r=0.763, p=0.002 ; r=0.698, p=0.001 ; r=0.717, p=0.006$, respectively). However, there was no significant correlation between ultrasound measurements and echocardiographic parameters of the mitral valve.

Conclusions: The subsegmental branches of the pulmonary artery can be assessed by IVUS. Patients with pulmonary hypertension in the setting of mitral stenosis have greater pulmonary arterial WT. The severity of WT is correlated with pulmonary artery pressure, but it is not associated with mitral valve area. Intravascular ultrasound may provide useful additional information in the management of patients with mitral stenosis.
\end{abstract}

Key words: pulmonary hypertension, mitral stenosis, intravascular ultrasound

\section{Streszczenie}

Wstęp: Przydatność ultrasonografii wewnątrznaczyniowej (intravascular ultrasound - IVUS) w ocenie gałęzi subsegmentalnych tętnicy płucnej była analizowana w nielicznych badaniach.

Cel: Ocena charakterystyki strukturalnej tętnicy płucnej za pomocą IVUS u chorych z ciasną stenozą mitralną.

Materiat i metody: Do badania włączono 21 kolejnych pacjentów (3 mężczyzn i 18 kobiet; średni wiek: $38 \pm 11$ lat) kierowanych do przezskórnej plastyki balonowej zastawki mitralnej. Gałęzie subsegmentalne odchodzące od prawej tętnicy dolnopłatowej oceniano za pomocą IVUS o częstotliwości $40 \mathrm{MHz}$ podczas cewnikowania prawego serca. Analizowano minimalną średnicę światła naczynia (minimal lumen diameter - MLD), średnicę zewnętrznej błony elastycznej (external elastic membrane diameter - EEMD), powierzchnię światła naczynia (lumen area - LA) oraz powierzchnię wytyczoną przez zewnętrzną błonę elastyczną (całkowita powierzchnia naczynia, total vessel area - TVA). Na podstawie tych danych wyliczono powierzchnię ściany naczynia (wall area - WA = TVA - LA),

Corresponding author/Adres do korespondencji:

Göksel Açar, Kartal Koșuyolu High Speciality Education and Research Hospital, Kartal, İstanbul, Turkey, tel: +905054424700,

e-mail: gokselacar81@hotmail.com

Praca wpłynęta: 9.04.2012, przyjęta do druku: 3.08.2012. 
grubość warstw intima-media (intima-media thickness - IMT = (EEMD - MLD)/2), względną grubość ściany (relative wall thickness RWT $=$ IMT/EEMD) oraz względną powierzchnię ściany (relative wall area - RWA $=$ WA/TVA).

Wyniki: Ocenę za pomocą IVUS udało się przeprowadzić bez powikłań u wszystkich pacjentów. Kilka spośród wskaźników anatomicznych ocenianych za pomocą IVUS korelowało z danymi hemodynamicznymi. Wartości IMT, RWT i RWA tętnicy płucnej istotnie korelowały z ciśnieniem skurczowym w tętnicy płucnej (odpowiednio $r=0,763, p=0,002 ; r=0,698, p=0,001 ; r=0,717$, $p=0,006$ ). Mimo to nie stwierdzono istotnych korelacji między pomiarami w IVUS a echokardiograficznymi parametrami oceny zastawki mitralnej.

Wnioski: Gałęzie subsegmentalne tętnicy płucnej mogą być ocenione za pomocą IVUS. Pacjenci z nadciśnieniem płucnym w przebiegu stenozy mitralnej mają większą grubość ściany tętnicy płucnej. Grubość tętnicy koreluje z ciśnieniem w tętnicy płucnej, ale nie z powierzchnią zastawki mitralnej. Ocena za pomocą IVUS może dostarczyć dodatkowych informacji przydatnych w postępowaniu z chorymi ze stenozą mitralną.

Słowa kluczowe: nadciśnienie płucne, stenoza mitralna, ultrasonografia wewnątrznaczyniowa

\section{Introduction}

Pulmonary arterial hypertension (PAH) is a serious complication of rheumatic mitral stenosis (MS). Moreover, elevated pulmonary artery pressure in patients with MS is an important determinant of intervention. Passive congestion in addition to the active vasoconstriction and vascular remodeling are the reported causes of PAH in patient with MS [1]. Also, presence of vascular remodeling may lead to limited improvement in pulmonary artery pressure after the treatment of stenosis [2]. Increased vessel wall thickness both in primary and secondary PAH was shown in animal and postmortem studies [3, 4]. Intravascular ultrasound (IVUS) is a safe and precise diagnostic method for imaging the vessel wall structures which has led to the rapid growth of the use of IVUS in the coronary circulation in the past few years. Ultrasound imaging of the pulmonary artery and its branches in humans also has been safely performed. However, its clinical use in the more distal vascular tree, which is responsible for vascular resistance, has been more limited [5].

\section{Aim}

We aimed to assess the structural characteristics of the subsegmental branch of pulmonary arteries by IVUS in the setting of severe mitral stenosis, and also to evaluate its relation with clinical and echocardiographic parameters.

\section{Material and methods}

\section{Study population}

The study population included 21 consecutive patients ( 3 men and 18 women; mean age: $38 \pm 11$ years), who were selected for percutaneous mitral balloon valvuloplasty (PMBV) on the basis of hemodynamic and echocardiographic criteria. Patients with mild or moderate MS, and more than mild mitral regurgitation, severe aortic valve stenosis and regurgitation, left atrial chamber and appendage thrombi, and also patients with unfavorable mitral valve anatomy were not included in the study. Additionally, patients with a history of other diseases and conditions known to cause secondary pulmonary hyperten- sion, such as lung disease, deep vein thrombosis and/or pulmonary emboli, connective tissue disease, and left ventricular systolic dysfunction (left ventricular ejection fraction $<50 \%$ ), were also not included in the study. The protocol was approved by the regional scientific ethical committee, and all enrolled subjects gave informed written consent.

\section{Echocardiographic measurements}

Echocardiographic examinations were performed by an experienced cardiologist who was blinded to hemodynamic and IVUS data of patients. Examinations were performed using a Vingmed System 5 ultrasound system (GE Medical Systems, Horten, Norway) equipped with a 2.53.5 $\mathrm{MHz}$ phased array transducer. $\mathrm{M}$-mode measurements included LV end-diastolic and end-systolic dimensions, interventricular septum, and posterior wall thickness calculations and LA diameter in the parasternal long-axis view. LV ejection fraction was estimated by modified Simpson's rule. Mitral valve area was determined by planimetry and pressure half-time methods in every patient. The peak and mean mitral valve transannular pressure gradients were measured by continuous-wave Doppler. Systolic pulmonary artery pressure (PAP) was measured with continuous-wave Doppler. The maximum peak tricuspid regurgitation velocity $(\mathrm{V})$ recorded from any view was used to determine right ventricular systolic pressure with the simplified Bernoulli equation (PAP $=4 \mathrm{~V} 2+\mathrm{RAP}$ ). Pulmonary artery systolic pressure was estimated from the sum of the trans-tricuspid gradient and right atrial pressure. The final values of all parameters were obtained after averaging over three cardiac cycles. All patients underwent a detailed transesophageal echocardiographic (TEE) evaluation to identify the suitability of valve apparatus for valvuloplasty. Mitral leaflet mobility, valvular and subvalvular thickening and calcification, degree of mitral regurgitation, presence of thrombus in left atrium and/or left atrial appendage, and interatrial septum structure were assessed by TEE. Transthoracic (TTE) and transesophageal echocardiographic examinations were performed according to the criteria of American Society of Echocardiography guidelines [6]. 


\section{Catheterization and intravascular ultrasound examination}

Right and left heart catheterization and hemodynamic measurements were performed with standard catheters. Following these measurements, a 0.014-inch guidewire was advanced through a $7 \mathrm{~F}$ right coronary artery guiding catheter. The IVUS catheter was advanced over the guidewire in the subsegmental branches of the right lower lobe pulmonary artery (i.e., as far as it was technically feasible to advance it). We used a $40 \mathrm{MHz}$ intravascular IVUS probe (Atlantis pro40, Boston Scientific Corporation, Natick, Massachusetts). All images were recorded on videotape, from which quantitative analyses were performed. The analysis and measurements of the intravascular ultrasound recordings were obtained by two independent observers, who were blinded to the hemodynamic data. Minimal lumen diameter (MLD), external elastic membrane diameter (EEMD), lumen area (LA), and area circumscribed by the external elastic membrane [the total vessel area (TVA)] were measured at end-diastole. From these measurements, wall area (WA $=$ TVA - LA), intima-media wall thickness $[I M=(E E M D-$ $M L D) / 2$ ], relative wall thickness (RWT = IMT/EEMD), and relative wall area (RWA $=$ WA/TVA) were derived.

\section{Statistical analysis}

Results are presented as mean \pm SD. Pearson correlation coefficient was used for parametric variables, and Spearman correlation analysis was used for categorical variables (version 11.5, SPSS, Chicago, IL). A $p$ value $<0.05$ was considered statistically significant.

\section{Results}

Clinical and echocardiographic characteristics of the study population are expressed in Table 1. We were able to perform the IVUS examination in all patients without complications (Fig. 1). Several IVUS anatomic indexes correlated with hemodynamic data (Table 2). Pulmonary artery IMT, RWT, and RWA correlated significantly with PAP $(r=0.763, p=0.002 ; r=0.698, p=0.001 ; r=0.717$, $p=0.006$, respectively) (Fig. 2). Therefore, greater vascular hypertrophy was associated with more severe pulmonary hypertension. However, there was no significant correlation between ultrasound measurements and age, mitral valve area, mean transmitral pressure gradient, and left atrial dimension (all $p>0.05$ ).

Table 1. Demographic and echocardiographic characteristics of patients

Tabela 1. Charakterystyka demograficzna i echokardiograficzna pacjentów

\begin{tabular}{lc} 
Parameter & Mean \pm SD \\
\hline Age [year] & $38 \pm 11$ \\
\hline Mitral valve area $\left[\mathrm{cm}^{2}\right]$ & $1.13 \pm 0.25$ \\
\hline Mitral maximum gradient $[\mathrm{mm} \mathrm{Hg}]$ & $22.27 \pm 6.60$ \\
\hline Mitral mean gradient $[\mathrm{mm} \mathrm{Hg}]$ & $12.42 \pm 4.58$ \\
\hline Left atrial diameter $[\mathrm{cm}]$ & $4.41 \pm 0.59$ \\
\hline Systolic pulmonary artery pressure $[\mathrm{mm} \mathrm{Hg}]$ & $52.10 \pm 14.84$
\end{tabular}

Mean left atrial pressure $[\mathrm{mm} \mathrm{Hg}]$ by catheterization $21.23 \pm 4.32$
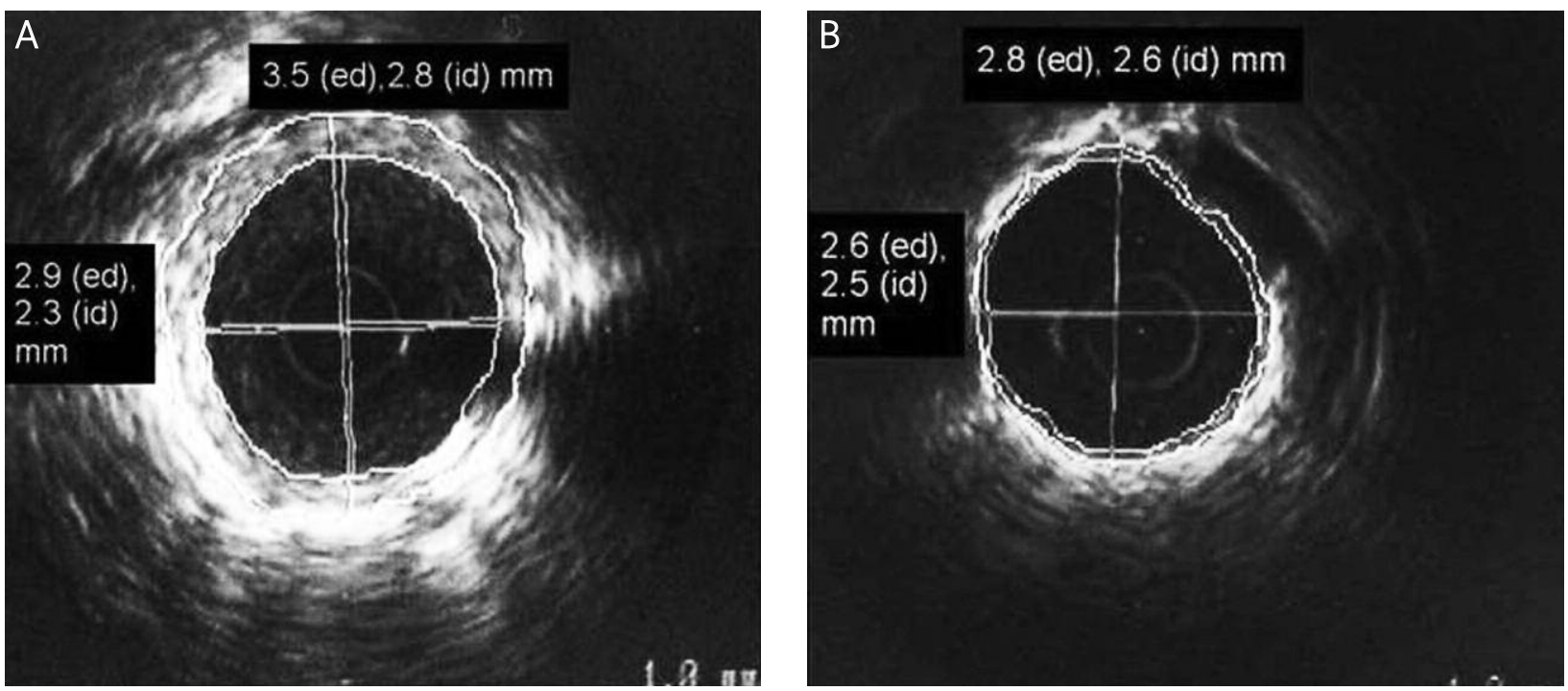

Fig. 1. A - Twenty-one year old female patient presented with hemoptysis; valvular area: $0.85 \mathrm{~cm}^{2}$, mean gradient: $14 \mathrm{~mm} \mathrm{Hg}$, systolic pulmonary artery pressure: $71 \mathrm{~mm} \mathrm{Hg}$. B - Thirty-seven year old female patient; valvular area: $1.10 \mathrm{~cm}^{2}$, mean gradient: $21 \mathrm{~mm} \mathrm{Hg}$, systolic pulmonary artery pressure: $49 \mathrm{~mm} \mathrm{Hg}$

Ryc. 1. A-Kobieta 21-letnia z krwiopluciem: powierzchnia zastawki 0,85 cm², średni gradient $14 \mathrm{~mm} \mathrm{Hg}$, ciśnienie skurczowe w tętnicy płucnej $71 \mathrm{~mm} \mathrm{Hg.} \mathrm{B} \mathrm{-} \mathrm{Kobieta} \mathrm{37-letnia:} \mathrm{powierzchnia} \mathrm{zastawki} \mathrm{1,10} \mathrm{cm²,} \mathrm{średni} \mathrm{gradient}$ $21 \mathrm{~mm} \mathrm{Hg}$, ciśnienie skurczowe w tętnicy płucnej $49 \mathrm{~mm} \mathrm{Hg}$ 
Table 2. Intravascular ultrasound findings of patients

Tabela 2. Dane z ultrasonografii wewnatrznaczyniowej u badanych pacjentów

\begin{tabular}{|c|c|}
\hline Parameter & Mean \pm SD \\
\hline Mean internal diameter [mm] & $2.83 \pm 0.60$ \\
\hline Mean EEM diameter [mm] & $3.32 \pm 0.52$ \\
\hline Mean wall thickness [mm] & $0.48 \pm 0.30$ \\
\hline Relative wall thickness (wall thickness/EEM diameter) & $0.14 \pm 0.08$ \\
\hline Wall area $\left[\mathrm{mm}^{2}\right]$ & $1.99 \pm 0.91$ \\
\hline Vessel area $\left[\mathrm{mm}^{2}\right]$ & $8.82 \pm 2.74$ \\
\hline Relative wall area (wall area/vessel area) & $0.25 \pm 0.12$ \\
\hline
\end{tabular}

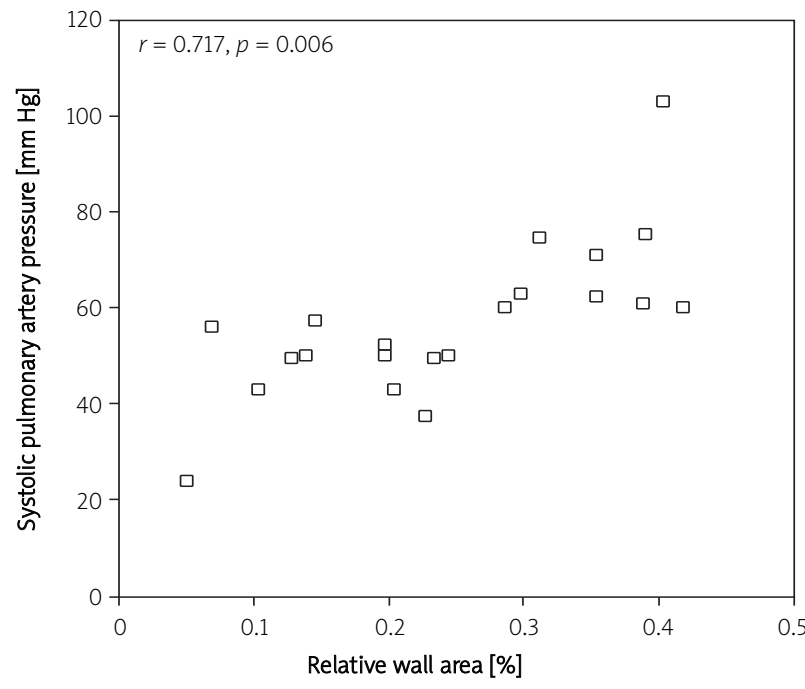

Fig. 2. Correlation between systolic pulmonary artery pressure and relative wall area

Ryc. 2. Korelacja między ciśnieniem skurczowym $w$ tętnicy płucnej a względna powierzchnią ściany naczynia

\section{Reproducibility}

Interobserver variability of measurements of IVUS parameters was calculated as the difference in two measurements of the same patient by two different observers divided by the mean value. Intraobserver variability was calculated as the difference in two measurements of the same patient by one observer divided by the mean value. Intraobserver and interobserver variabilities were less than $10 \%$ for all IVUS parameters.

\section{Discussion}

In our study, we showed that patients with pulmonary hypertension in the setting of mitral stenosis have greater pulmonary arterial IMT. Moreover, the severity of structural abnormalities found on IVUS is directly correlated with hemodynamic findings; however, there is no associ- ation between the ultrasound measurements and mitral valve area and mean transmitral pressure gradient. There are many causes of pulmonary hypertension which were divided into five groups according to Word Health Organization (WHO) criteria. Mitral stenosis, as a left-sided heart disease, is one of the most common causes of secondary PAH (WHO group II). Tandon and Kasturi [3] showed that pulmonary artery intimal edema, fibrosis, and, more importantly, variable degrees of muscularization, often suggesting the incipient formation of a second media in their study which included extensive histopathologic examination of ninety patients and ten cadavers with pulmonary hypertension secondary to severe MS. They also reported that the arteries and arterioles were often occluded by thrombi in various stages of organization, and the freshly formed channels tended to acquire a muscular lining, arterioles were muscularized in all cases, and in many there was a pronounced intimal proliferation. To date, there is only one study examining the IVUS imaging of patients with secondary PAH in the setting of MS [5]. This study showed that there were no differences between the left and right lungs for all IVUS measurements. In contrast, anatomic abnormalities were more severe in the lower lobes than in the upper lobes, as evidenced by differences in the percent WT, and by the ratios of lumen diameter to WT and of LA to TVA. Furthermore, the authors found that wall hypertrophy on IVUS was significantly less pronounced in patients with mitral stenosis despite a trend for higher pulmonary pressures compared to other patients in their study. However, they did not provide data on the relation between IVUS measurement and degree of mitral valve stenosis. In our study, we did not find any association between the ultrasound measurements and the degree of mitral valve stenosis, which is determined by mitral valve area and mean and maximal pressure gradients; however, we found that greater vascular hypertrophy was associated with more severe pulmonary hypertension. The PAH is a serious complication of MS, so it is important to learn what the basic pathophysiology of this disorder is. It can be derived from the following equation: according to Ohm's law, pressure $(P)$ equals flow $(Q)$ times resistance $(R)$ [pressure differences $=Q \times R$ ]. Therefore, PAPm $-\mathrm{PVPm}$ $=\mathrm{Q} \times \mathrm{PVR}$; from this measurement, $\mathrm{PAPm}=(\mathrm{Q} \times \mathrm{PVR})+$ PVPm (PAPm - mean PAP, PVPm - mean pulmonary venous pressure, PVR - pulmonary vascular resistance, $\mathrm{Q}$ - cardiac output) was derived. This latter equation clearly shows that the PAP is determined by the cardiac output, pulmonary vascular resistance, and pulmonary venous pressure. Left atrial pressure is equal to pulmonary venous pressure in the absence of a pulmonary venous disease. The elevated PAP was caused by the increase in left atrial pressure in the patients with MS. During exercise, the cardiac output can be increased by increasing either the stroke volume or the heart rate in a healthy adult; however, patients with severe MS have a fixed cardiac output where- 
as the left atrial and pulmonary venous pressures are increased. Eventually, this increase in left atrial pressure may lead to pulmonary edema. This condition may be compensated by an active pre-capillary response which gives rise to increased resistance in the pulmonary arterial bed. This response is most likely a combination of vasoconstriction and vascular remodeling associated with structural alterations. The anatomical changes are initially a protective reflex which may prevent further injury; however, during the course of time these changes may lead to a second stenosis and contribute to the development of PAH $[2,3]$. Pulmonary venous pressure is initially determined by the afterload parameters, such as mitral valve area, mean mitral gradient, and left ventricle end-diastolic pressure; and later on, pulmonary artery remodeling leads to reduced preload and contributes to determination of pulmonary venous pressure. The extent of pulmonary vascular remodeling correlates with the severity and course of the pulmonary venous pressure. The response of pulmonary artery structure, such as endothelium, to elevated pulmonary venous pressure is also important in this kind of anatomical changes [7]. The response is affected by genetic and environmental factors. Moreover, angiotensin II, endothelin-1, matrix metalloproteinase enzyme activities, norepinephrine and nitric oxide levels, sympathovagal modulation, and other (unknown) parameters might have appreciable effects on pulmonary artery remodeling [5, 8-11]. In our study, we did not find any association between the ultrasound measurement and the degree of mitral valve stenosis, as a representative of increased afterload, and age, as a representative of time of exposure to increased afterload. This might be considered as individual variation. This study was performed on patients with severe MS, namely "secondary stenosis". In other words, secondary stenosis formed by remodeling has become the cause of PAH after passing through the phase of being the result of $\mathrm{PAH}$. Thus, no relationship with the parameters of MS was detected but it was found to be significantly related to PAP. In the light of the abovementioned data, remodeling may be suggested to be related to MS parameters more than PAP in patients in the early phase of MS in which secondary stenosis has not developed. However, this is just speculation and must be confirmed by a study. Vascular remodeling is not uncommon in patients with MS, and it is related to the absence of the expected decline in PAP [2]. Thus, determination of remodeling using IVUS may be beneficial for deciding on valvular intervention. Remodeling was shown to be associated with increase of connective tissue in the intima-media layer, especially in subsegmental branches [11]. In previous studies, $20 \mathrm{MHz}$ and $30 \mathrm{MHz}$ IVUS catheters were used. In these studies, difficulties in distinguishing the vascular wall layers and limitations of investigating the distal branches were reported with the use of the abovementioned catheters [5, 12-16]. In our study, subsegmental branches of the pulmonary artery were evaluated with $40 \mathrm{MHz}$ catheters in patients with MS. In this way, intravascular layers and external elastic membrane were visualized easily, especially in subsegmental branches that determine the vascular resistance.

In this study, laboratory parameters such as endothelin-1, angiotensin II and matrix metalloproteinase that may predict the pulmonary vascular response were not examined. Genetic and biochemical predictors of individual variability and the relationship with the degree of remodeling should be further investigated. The effects of the decrease of pulmonary venous pressure by treating mitral stenosis on the pulmonary artery pressure and the thickness of pulmonary artery subsegmental branches should also be evaluated in further studies.

\section{Conclusions}

Alterations of pulmonary artery subsegmental branches could be detected by IVUS. Vascular wall thickness of the pulmonary artery subsegmental branches is markedly increased in patients with severe MS. This increased thickness is related to systolic pulmonary artery pressure but not with mitral valve area, maximum and mean gradient or left atrial diameter. Mitral valve area and mean gradient, which are important in the intervention decision, may not always be useful in defining the disease severity. Determining increased IMT by the use of IVUS may be helpful in detecting patients with remodeling and also in the intervention decision. These findings should be confirmed with further studies.

\section{References}

1. Humbert M, Morrell NW, Archer SL, et al. Cellular and molecular pathobiology of pulmonary arterial hypertension. J Am Coll Cardiol 2004; 43 (12 Suppl S): 13-24.

2. Ribeiro PA, al Zaibag M, Abdullah M. Pulmonary artery pressure and pulmonary vascular resistance before and after mitral balloon valvotomy in 100 patients with severe mitral valve stenosis. Am Heart J 1993; 125: 1110-1114.

3. Tandon HD, Kasturi J. Pulmonary vascular changes associated with isolated mitral stenosis in India. Br Heart J 1975; 37: 26-36.

4. Jeffery TK, Wanstall JC. Pulmonary vascular remodeling: a target for therapeutic intervention in pulmonary hypertension. Pharmacol Ther 2001; 92: 1-20.

5. Bressollette E, Dupuis J, Bonan R, et al. Intravascular ultrasound assessment of pulmonary vascular disease in patients with pulmonary hypertension. Chest 2001; 120: 809-815.

6. Gottdiener JS, Bednarz J, Devereux R, et al. American Society of Echocardiography recommendations for use of echocardiography in clinical trials. J Am Soc Echocardiogr 2004; 17: 1086-1119.

7. Meyrick B, Reid L. Pulmonary hypertension. Anatomic and physiologic correlates. Clin Chest Med 1983; 4: 199-217.

8. Kasahara Y, Tuder RM, Cool CD, et al. Endothelial cell death and decreased expression of vascular endothelial growth factor and vascular endothelial growth factor receptor 2 in emphysema. Am J Respir Crit Care Med 2001; 163: 737-744. 
9. Giaid A, Saleh D. Reduced expression of endothelial nitric oxide synthase in the lungs of patients with pulmonary hypertension. N Engl J Med 1995; 333: 214-221.

10. Achcar RO, Demura Y, Rai PR, et al. Loss of caveolin and heme oxygenase expression in severe pulmonary hypertension. Chest 2006; 129: 696-705.

11. Launay JM, Herve P, Peoc'h K, et al. Function of the serotonin 5 -hydroxytryptamine $2 \mathrm{~B}$ receptor in pulmonary hypertension. Nat Med 2002; 8: 1129-1135.

12. Scott PJ, Essop AR, al-Ashab W, et al. Imaging of pulmonary vascular disease by intravascular ultrasound. Int J Card Imaging 1993; 9: 179-184.

13. Rodés-Cabau J, Domingo E, Román A, et al. Intravascular ultrasound of the elastic pulmonary arteries: a new approach for the evaluation of primary pulmonary hypertension. Heart 2003; 89: 311-316.

14. Berger RMF, Cromme-Dijkhuis AH, Hop WCJ, et al. Pulmonary arterial distensibility assessed by intravascular ultrasound in children with congenital heart disease. An indicator for pulmonary vascular disease? Chest 2002; 122: 549-557.

15. Ivy DD, Neish SR, Knudson OA, et al. Intravascular ultrasonic characteristics and vasoreactivity of the pulmonary vasculature in children with pulmonary hypertension. Am J Cardiol 1998; 81: 740-748.

16. McLeod KA, Gerlis LM, Williams GJ. Morphology of the elastic pulmonary arteries in pulmonary hypertension: a quantitative study. Cardiol Young 1999; 9: 364-370. 